\title{
PENGARUH METODE SUUGESTIPEDIA TERHADAP KETERAMPILAN MEMBACA PUISI pada sisWa Kelas 4 SDN CIWALET, tasikmalaya
}

\author{
PENI SRIRAHAYU', ANGGIA SUCI PRATIWI², SUNANIH ${ }^{3}$ \\ Universitas Muhammadiyah Tasikmalaya \\ Corresponding author: fenisri08@gmail.com
}

Pertama Diterima: 20 Juli 2020

Bukti Akhir Diterima: 30 Desember 2020

\begin{abstract}
Abstrak
Penelitian ini bertujuan untuk mengetahui pengaruh metode sugestopedia terhadap keterampilan membaca puisi pada mata pelajaran bahasa Indonesia kelas IV di SDN Ciwalet. Penerapan pembelajaran puisi dalam Kurikulum 2013 bertujuan agar siswa mampu menikmati dan memanfaatkan karya puisi untuk memperluas wawasan, memperluas budi pekerti, serta meningkatkan pengetahuan dan kemampuan berbahasa. Jenis penelitian ini adalah pendekatan kuantitatif dengan metode PreEksperimental Design (One-Group Pretest-Posttest Design) yaitu sebuah eksperimen yang dilakukan dengan adanya pretest sebelum diberi perlakuan. Dengan demikian hasil perlakuan dapat diketahui lebih akurat, karena dapat dibandingkan dengan keadaan sebelum diberi perlakuan.Hasil sebelum menerapkan metode sugestopedia, Pretes yang diberikan kepada siswa menunjukkan bahwa tidak ada siswa yang memperoleh nilai dengan kategori sangat tinggi (0\%), kategori tinggi sebanyak 1 orang (4,2\%), kategori sedang sebanyak 10 orang $(41,7 \%)$, klasifikasi nilai siswa dengan kategori rendah sebanyak 13 orang $(54,2 \%)$, dan tidak ada siswa yang memperoleh nilai dengan kategori sangat rendah $(0 \%)$. Hasil sesudah menerapkan metode sugestopedia, Posttest yang diberikan kepada siswa menunjukkan bahwa siswa memperoleh nilai dengan kategori sangat tinggi yang dicapai sebanyak 11 orang (45,8\%), kategori tinggi sebanyak 13 orang $(54,2 \%)$. Hasil dari penelitian ini yakni adanya peningkatan kualitas membaca puisi pada siswa kelas IV SDN Ciwalet dengan diterapkannya metode sugestopedia terhadap pembelajaran tersebut. Peningkatan terlihat jelas pada perbandingan nilai rata-rata siswa sebelum dan sesudah diterapkannya metode sugestopedia. Sebelum diterapkannya metode sugestopedia rata-rata siswa sangat rendah dengan nilai 68,58 dan sesudah diterapkannya metode sugestopedia mengalami peningkatan dengan nilai rata-rata 89,58.
\end{abstract}

Kata Kunci: Metode, Sugestopedia, Puisi, Keterampilan, Membaca.

\begin{abstract}
This study aims to determine the effect of suggestopedia methods on poetry reading skills in fourth grade Indonesian subjects at Ciwalet Elementary School. The application of poetry learning in the 2013 curriculum aims to enable students to enjoy and utilize poetry to broaden their horizons, broaden their character, and improve their knowledge and language skills.This type of research is a quantitative approach using a type of research using the Pre-Experimental Design (One-Group Pretest-Posttest Design) method, an experiment conducted in the presence of a pretest before being treated. Thus the results of the treatment can be known to be more accurate, because it can be compared with the situation before being treated.The results before applying the sugestopedia method, Pretest given to students showed that there were no students who scored very high categories ( $0 \%)$, high categories of 1person (4.2\%), moderate categories of 10 people (41.7\%), the classification of students' scores in the low category was 13 people (54.2\%), and there were no students who scored in the very low category (0\%). The results after applying the sugestopedia method, Posttest given to students shows that students get very high grades achieved by 11 people (45.8\%), high categories by 13 people (54.2\%). The results of this study are an increase in the quality of poetry reading in the fourth grade students of Ciwalet Elementary School by applying the sugestopedia method to the learning. The improvement was clearly seen in the comparison of the average scores of students before and after the implementation of the suggestopedia method. Before the implementation of the suggestopedia method the average student was very low with a
\end{abstract}


value of 68.58 and after the implementation of the suggestopedia method an increase with an average value of 89.58 .

Keywords: Method, Suggestopedia, Poetry, Skills, Reading.

\section{PENDAHULUAN}

Dalam dunia pendidikan pembelajaran dikemas kedalam empat aspek keterampilan bahasa, yaitu menyimak, membaca, berbicara dan menulis. Keempat keterampilan bahasa merupakan aspek kemampuan berbahasa menjadi sasaran utama peserta didik. Pembelajaran bahasa yang selalu ada di sekolah formal seringkali dianggap remeh padahal tidak sedikit pelajar yang kesulitan dalam menguasai empat keterampilan berbahasa tersebut, salah satunya keterampilan membaca. Membaca merupakan salah satu proses perkembangan seperti halnya ketiga keterampilan berbahasa lainnya. Membaca juga membutuhkan waktu, menurut pengalaman dan latihan yang terus menerus serta pengajaran yang kreatif dari seorang guru.

Terdapat pertimbangan penetapan metode dalam belajar, berbagai macam metode belajar saat ini yang sangat variatif dapat membantu guru dalam melakukan proses belajar mengajar didalam kelas, diluar kelas, maupun ditempat-tempat lain yang sudah ditetapkan sebelumnya. Akan tetapi, seorang guru hendaknya selalu meperhatikan banyak faktor dalam memilih dan menetapkan metode tersebut. Ketepatan dalam memilih metode mengajar akan berkolerasi dengan hasil yang diperoleh setelah pembelajaran berlangsung.

Sugestopedia mencoba memanfaatkan pengaruh tersebut serta mengalihkan dan mengarahkannya untuk mengoptimalkan pembelajaran. Ciri sugestopedia yang paling mencolok adalah dekorasi kelas, perabot/mebel kelas, susunan /pengaturan kelas, penggunaan musik dan perilaku guru yang otoritatif. Russel (dalam Lou 2011:217) menjelaskan empat tahapan dalam sugestopedia sebagai berikut.

\section{Tabel 1}

Tahap-tahap Metode Sugestopedia

\begin{tabular}{|c|l|l|}
\hline No & $\begin{array}{l}\text { Tahap-Tahap Metode } \\
\text { Sugestopedia }\end{array}$ & \multicolumn{1}{|c|}{ Deskripsi } \\
\hline 1 & Presentasi & $\begin{array}{l}\text { Dalam tahapan ini siswa dibuat rileks dan diberi sugesti positif } \\
\text { (saran bukan hipnotis) bahwa belajar itu mudah dan } \\
\text { menyenangkan.ss }\end{array}$ \\
\hline 2 & Aktif konser & $\begin{array}{l}\text { Kegiatan yang aktif antara guru dan murid dalam belajar. Aktif } \\
\text { konser yang digunakan untuk memperkenalkan materi baru, } \\
\text { dibacakan secara dramatik pada para pelajar selagi musik diputar } \\
\text { sebagai latarnya, biasanya dengan musik klasik atau romantik. }\end{array}$ \\
\hline 3 & Pengulangan pasif & $\begin{array}{l}\text { Guru memberikan kesempatan siswa untuk memahami apa yang } \\
\text { dipelajari dalam tahap aktif konser, alunan musik dapat } \\
\text { diperdengarkan dalam tahap ini. }\end{array}$ \\
\hline
\end{tabular}




\begin{tabular}{|c|l|l|}
\hline 4 & Latihan & $\begin{array}{l}\text { Dapat digunakan permainan, untuk mengulang dan } \\
\text { mengembangkan apa yang dipelajari. }\end{array}$ \\
\hline
\end{tabular}

Pada penelitian ini, peneliti menjelaskan ada komponen persiapan dalam kelas agar tercipta suasana yang menggembirakan dan proses belajar yang efektif, yaitu sugesti positif, menghilangkan asumsi negatif dan musik. Menurut Lozanov (dalam Russel 2011:210) kelebihan dan kekurangan metode suggestopedia, yaitu di antara kelebihan yang dimiliki metode ini adalah bisa menumbuhkan kesenangan dalam diri siswa, dengan tokoh yang diperankan siswa, dengan gaya non-evaluatif guru dan materi ajar yang menarik, termasuk penggunaan lagu klasik. Di samping itu, para siswa juga bisa menumpuk perasaan kerja sama yang kuat antara mereka sendiri karena mereka saling tolong menolong dalam menyerap semua pelajaran yang diterima. Adapun kelemahan metode sugestopedia antara lainbiaya yang terlalu mahal, belum ada ketentuan dan persiapan bagi tingkat menengah dan lanjutan untuk pemahaman membaca dan menyimak terlalu terbatas, bahan masukan secara pedagogik dipersoalkan, hanya dapat digunakan bagi kelompok kecil, menjengkelkan dan menggelisahkan bagi orang-orang yang tidak menyukai penggunaan lagu klasik.

Sugestopedia adalah suatu metode pembelajaranyang mampu mensugesti peserta didik, tetapi untuk tingkat sugesti yang lebih sederhana dengan memperdengarkan musik klasik sehingga mampu menenangkan dan membuat peserta didik terasa lebih rileks dan santai dalam pembelajaran. Membaca adalah salah satu keterampilan dalam pembelajaran bahasa Indonesia untuk meningkatkan pengetahuan peserta didik dalam pembelajaran bahasa Indonesia dengan baik dan benar terutama dalam pembelajaran teks tanggapan. Teks tanggapan merupakan kegiatan pembelajaran yang bertujuan menyampaikan kritik atau pendapat terhadap apa yang didengar dan yang disampaikan oleh lawan bicara.

Keterampilan membaca puisi atau poetry reading muncul di Indonesia sejak tahun 1960. Istilah ini dibawa ke Indonesia oleh W.S Rendra yang merupakan oleh-oleh atas kepulanganya dari Amerika. Sebelumnya di Indonesia di kenal dengan istilah deklamasi. Hasanuddin (2002:14) menyatakan bahwa puisi merupakan pernyataan perasaan yang imajinatif yaitu perasaan yang direkakan atau yang diangankan. Puisi merupakan pernyataan dari keadaan atau kualitas kehidupan manusia Afrarudin (2015:14). Jadi, dapat penulis simpulkan bahwa puisi adalah sebuah karya sastra yang mampu mengekspresikan pikiran dan juga membangkitkan emosional dalam susunan irama yang ditulis menggunakan kata-kata yang indah.

Pengertian teknik cara membaca puisi yang baik tidak hanya dilihat dari segi vokalnya saja dan tidak dapat dilihat dari segi ekspresinya dalam penampilan. Dari sini jelas, bahwa untuk bisa membaca puisi dengan baik tidak hanya diperlukan keterampilan membaca saja, tetapi juga harus disertai dengan keterampilan menampilkan puisi. Adapun pengertian dari ketiga tersebut sebagai berikut.

a. Ekspresi: mimik wajah yang menunjukkan perasaan hati (senang, sedih, bahagia, marah). Ekspresi seseorang pembaca puisi yang bersifat khas dan tidak dimiliki atau dapat ditiru oleh orang lain. Oleh karena itu, gaya merupakan aktivitas kreatif yang bersifat individual dan 
subjektif.Ekspresi juga disebut mimik. Mimik merupakan petunjuk apakah seseorang sudah benar-benar dapat menjiwai atau meresapkan puisi itu dengan sebaik-baiknya. Mimik yang seakan-akan dipaksakan akan lebih banyak menggelikan hati penonton. Mimik haruslah keluar sewajarnya tanpa dipaksa-paksa atau dibuat-buat. Mimik tidak mungkin dapat diatur sebelumnya, tetapi biasanya keluar menurut kewajaran secara spontan (Situmorang, 1974:55).

b. Gerak juga termasuk respresentasi pada saat membaca puisi, gerak atau actingmerupakan perilaku pembaca puisi ketika membacakan puisi. Gerak ini merupakan perwujudan dari penjiwaan terhadap puisi (Gani, 2015:76). Gerak visualisasi merupakan representasi dari makna puisi. Wiyanto (2005:47) mengemukakan bahwa gerak tangan, kepala, badan, dan mimik (gerak raut muka) yang tepat dapat menghidupkan pembacaan puisi. Akan tetapi, gerak-gerik itu tidak boleh dibuat-buat. Gerak-gerik yang tepat adalah gerak gerik yang merupakan ekspresi dari dalam sebagai wujud penghayatan terhadap puisi yang dibacanya.

c. Intonasi: ketepatan penyajian tinggi rendah nada.

d. Penampilan: seorang pembaca puisi yang baik tidak hanya dilihat dari cara dia membaca puisi, namun juga dapat dilihat dari cara dia menampilkan puisi yang dibacanya.Menampilkan puisi dapat dikatakan atau bisa dimasukkan dalam kategori seni gerak, dimana gerak dan olah tubuh mengikuti alur puisi yang sedang dibaca.

Kegiatan membaca puisi ini sangat kurang diminati dan dianggap sulit oleh siswa, hal ini disebablan oleh beberapa hal sebagai berikut:

1. Minat siswa dalam mempelajari membaca puisi rendah dan siswa belum dapat membaca puisi dengan baik,

2. Siswa kurang mengerti tentang teknik pembacaan puisi yang baik,

3. Guru belum optimal dalam mengajar membaca puisi,

4. Sebagai guru merasa kesulitan dalam proses pembelajarannya, ketika bertemu dengan pembelajaran membaca puisi,

5. Metode yang digunakan kurang tepat karena kurangnya pemanfaatan media atau model yang mendukung saat pembelajaran membaca puisi.

Dalam upaya menerapkan suatu metode yang relevan ada beberapa pertimbangan dalam pemilihan suatu metode yang akan digunakan. Pangewa (dalam Embo 2013:27) mengemukakan, "Ada hal-hal yang harus dipertimbangkan dalam menerapkan suatu metode" sebagai berikut.

1. Tujuan berbagai jenis dan fungsinya.

2. Subjek didik yang berbagai tingkat kematangan/jenjangnya.

3. Situasi dalam berbagai keadaan/kondisinya.

4. Fasilitas yang berbagai kualitas dan kuantitasnya.

5. Pribadi guru atau calon guru serta kemampuan profesi yang berbeda-beda. 
Sugestopedia adalah metode pengajaran yang didasarkan pada pemahaman modern tentang bagaimana otak manusia bekerja dan bagaimana kita belajar paling efektif. Sugestopedia berasal dari kombinasi dua kata yaitu saran dan ilmu mendidik. Ilmu mendidik adalah pembahasan dari strategi pengajaran dan metode pengajaran dari seorang guru. Suatu pembelajaran akan lebih epektif jika metode yang digunakan guru juga efektif, dan salah satu metode efektif adalah pembelajaran dengan sugestopedia.

Peneliti yang memiliki relevansi terhadap membaca puisi menggunakan metode suggestopedia yang menjadi kajian penelitian ini dilakukan oleh Listiani (2014) dengan judul "Penerapan Metode Sugestopedia untuk Meningkatkan Kemampuan Menulis Puisi pada Mata Pelajaran Bahasa Indonesia". Temuan dalam penelitian tersebut bahwa metode sugestipedia dapat meningkatkan keterampilan menulis puisi pada siswa kelas 5 SD 6 Cikadang Kabupaten Bandung Barat. Berdasarkan penelitian tersebut, penelitian ini dilakukan untuk mengetahui pengaruh metode sugestipedia terhadap keterampilan membaca puisi siswa kelas 4 SD N Ciwalet.

\section{METODE}

Pendekatan penelitian yang digunakan pendekatan kuantitatif dengan desain PreEksperimental (One-Group Pretest-Posttest Design), yaitu sebuah eksperimen yang dilakukan dengan adanya pretest sebelum diberi perlakuan. Dengan demikian, hasil perlakuan dapat diketahui lebih akurat, karena dapat dibandingkan dengan keadaan sebelum diberi perlakuan.

$$
\mathrm{O}_{1 \times} \mathrm{XO}_{2}
$$

\section{Gambar 2 Desain Penelitian Jenis One-Group Pretest-Posttest}

Keterangan:

$\mathrm{O}_{1}=$ Perlakuan sebelum menggunakan metode sugestopedia

$\mathrm{O}_{2}=$ Tes setelah menggunakan metode sugestopedia

Peneliti menggunakan metode quasi eksperimen yang bertujuan untuk mengetahui suatu gejala atau pengaruh yang timbul sebagai akibat dari adanya perlakuan tertentu. Perlakuan didalam penelitian ini, yaitu pengaruh metode sugestopedia terhadap keterampilan membaca puisi siswa kelas 4 SDN Ciwalet.

Populasi dalam penelitian ini adalah seluruh siswa kelas 4 di SDN Ciwalet yang terdiri dari 12 orang laki-laki dan 12 orang perempuandengan jumlah keseluruhan sebanyak 24 orang.Pengambilan sampel dilakukan dengan teknik samplingjenuh. Samplingjenuh bila jumlah populasi relatif kecil atau kurang dari 30 orang dan dimana populasi dijadikan sampel. Oleh karena itu, terhadap keseluruhan siswa untuk pengambilan sampel dalam penerapan metode sugestopediapada pelajaran bahasa Indonesia yaitu membaca puisi sebanyak 24 orang. Dalam penelitian ini peneliti memilih sampel siswa kelas 4 di SDN Ciwalet dengan jumlah siswa 24 orang, yang terdiri dari 12 orang siswa laki-laki, dan 12 orang siswa perempuan. 
Ada dua variabel yang diteliti dalam penelitian ini, yaitu variabel bebas atau variabel (x), yang artinya adalah hal yang mampu mempengaruhi penelitian, dan yang kedua adalah variabel terikat atau variabel (y) yang artinya adalah hal yang dipengaruhi atau yang timbul akibat dari variabel bebas.

Variabel Bebas (X) : Metode Sugestopedia

Variabel Terikat (Y) : Keterampilan membaca puisi

1. Teknik pengumpulan data

Untuk memperoleh data yang diharapkan maka dalam suatu penelitian diperlukan teknik pengumpulan data. Langkah ini sangat penting karena data yang dikumplkan nanti akan digunakan dalam menguji hipotesis. Dalam melakukan teknik pengumpulan data, harus diseusaikan dengan data yang diperlukan. Pada penelitian ini, teknik pengumpulan data yang digunakan adalah:

a. Observasi

b. Wawancara

1) Wawancara Kepada Guru Kelas 4

2) Wawancara Kepada Siswa

3) Tes

2. Teknik analisis data

Dalam penelitian ini data yang digunakan adalah data kuantitatif, dikatakan sebagai data kuantitatif karena gambaran datanya menggunakan ukuran, jumlah atau frekuensi yaitu nilai membaca puisi siswa.

\section{HASIL DAN PEMBAHASAN}

Penelitian ini merupakan penelitian deskriptif kuantitatif yang bertujuan untuk mengetahui bagaimana pengaruh metode sugestopedia terhadap keterampilan membaca puisi pada siswa kelas IV yang berjumlah 24 orang di SDN Ciwalet, Desa Wangunsari, Kecamatan Bantarkalong, Kabupaten Tasikmalaya. Guna mengetahui pengaruh metode sugestopedia terhadap keterampilan membaca puisi dalam pembelajaran bahasa Indonesia, maka penulis melakukan penelitian sesuai dengan tahap-tahap yang telah dijelaskan pada bab sebelumnya.

Dalam penelitian ini dilakukan sebanyak 4 kali perlakuan, di mana setiap 1 perlakuan dilakukan selama 2 hari. Perlakuan ke-1 peneliti menjelaskan tentang bagaimana langkah-langkah membaca puisi agar siswa dalam membaca sesuai dengan langkah-langkah yang baik dan benar. Perlakuan ke-2 peneliti membimbing siswa untuk mengamati puisi yang dipelajari dengan menggunakan rangsangan alunan musik barat kemudian disela-sela pembelajaran peneliti memberikan sugesti positif kepada siswa agar mampu membaca puisi dengan baik dan benar. Perlakuan ke-3 peneliti membimbing siswa untuk mengamati puisi yang telah dipelajari dengan eksplorasi dalam membaca puisi dengan menggunakan intonasi, penghayatan, gerak, dan artikulasi. Perlakuan ke-4 peneliti membimbing siswa untuk kembali mengamati tentang puisi yang telah dipelajari kemudian di sela-sela pembelajaran peneliti memberi sugesti positif terhadap siswa 
bahwa belajar itu mudah dan menyenangkan agar siswa mampu membaca puisi dengan baik dan benar sesuai langkah-langkah yang telah disampaikan pada perlakuan pertama.

a. Hasil Pre-test

Pada pembelajaran membaca puisi sebelum menggunakan metode sugestopedia, peneliti memaparkan dan menjsselaskan mengenai pengertian puisi dan langkah-langkah membaca puisi. Kemudian peneliti membuat soal dengan bercerita, selanjutnya peneliti memberi tugas untuk menulis puisi dengan dengan tema yang ditentukan (Pemandangan). Sehingga siswa menggunakan imajinasinya sendiri atas apa yang mereka pikirkan. Setelah itu peneliti memberi kesempatan kepada siswa untuk membacakan karyanya. Dengan menggunakan cara tersebut, peneliti dapat mengetahui data siswa yang memiliki rasa percaya diri dalam membaca puisi di depan kelas. Pembelajaran terbilang sepi dan tenang. Posisi duduk siswa seperti pada umumnya di sekolah lain, yakni menggunakan meja dan kursi serta duduk secara berkelompok.

Selama pembelajaran berlangsung suasana kelas terbilang cukup tenang. Meskipun masih ada satu, dua orang siswa yang suka mengganggu dan sering bertingkah menjahili teman duduknya di kelas. Keaktifan siswa tersebut lantas tidak membuat peneliti diam saja. Kemudian peneliti bertanya kepada siswa tersebut tentang apa yang telah dijelaskan sebelumnya. Suasana kembali hening ketika akhirnya peneliti bertanya pada setiap siswa secara bergantian dan acak mengenai materi yang telah disampaikan oleh peneliti. Dalam proses pembelajaran ini peneliti menyelipkan tanya jawab untuk mengetahui seberapa jauh siswa memahami pembelajaran membaca puisi.

Sebaran nilai pre-testyaitu sebelum menerapkan metode sugestopedia, secara analisis statistik deskriptif menggambarkan perolehan nilai siswa mulai yang tertinggi hingga yang terendah. Jumlah sampel dalam penelitian ini adalah 24 siswa. Kemampuan siswa membaca puisi tanpa metode sugestopedia dengan jumlah sampel 24 dapat dilihat pada tabel di bawah ini.

Tabel 2

Kategori Skor Kemampuan Membaca Puisi

Sebelum Menerapkan Metode Sugestopedia

\begin{tabular}{|c|c|c|c|}
\hline $\begin{array}{c}\text { Interval } \\
\text { Nilai }\end{array}$ & Kategori & $\begin{array}{l}\text { Frekuensi } \\
\text { (f) }\end{array}$ & $\begin{array}{c}\text { Persentase } \\
(\%)\end{array}$ \\
\hline $90-100$ & Sangat tinggi & 0 & 0 \\
\hline $80-89$ & Tinggi & 1 & 4,2 \\
\hline $70-79$ & Sedang & 10 & 41,7 \\
\hline $40-69$ & Rendah & 13 & 54,2 \\
\hline $0-39$ & Sangat rendah & 0 & 0 \\
\hline \multicolumn{2}{|c|}{ Jumlah } & 24 & 100 \\
\hline
\end{tabular}

Berdasarkan tabel tersebut dapat digambarkan bahwa perolehan nilai untuk klasifikasi tersebut menunjukkan bahwa kelompok kategori sangat tinggi memiliki rentang nilai 90-100, 
kelompok kategori tinggi dengan rentang nilai 80-89, kelompok ketegori sedang dengan rentang nilai 70-79, kelompok kategori rendah dengan rentang nilai 40-69, dan kelompok kategori sangat rendah memiliki rentang nilai 39 ke bawah.Hasil klasifikasi nilai pretestkemampuan membaca puisi sebelum menerapkan metode sugestopedia, menunjukkan bahwa tidak ada siswa yang memperoleh nilai dengan kategori sangat rendah. Pretest yang diberikan kepada siswa menunjukkan bahwa tidak ada siswa yang memperoleh nilai dengan kategori sangat tinggi (0\%), kategori tinggi sebanyak 1 orang (4,2\%), kategori sedang sebanyak 10 orang $(41,7 \%)$, klasifikasi nilai siswa dengan kategori rendah sebanyak 13 orang $(54,2 \%)$, dan tidak ada siswa yang memperoleh nilai dengan kategori sangat rendah (0\%). Hal tersebut menunjukkan bahwa kemampuan siswa dalam membaca puisi sebelum menerapkan metode sugestopedia tergolong rendah.

\section{Tabel 3}

Deskripsi Nilai Hasil Pretest Kemampuan MembacaPuisi Sebelum Menerapkan Metode Sugestopedia

\begin{tabular}{|c|c|}
\hline Statistik & Nilai Statistik \\
\hline Sampel & 24 \\
\hline Nilai Terendah & 57 \\
\hline Nilai Tertinggi & 82 \\
\hline Nilai Tengah & 68,50 \\
\hline Rata-rata (mean) & 68,58 \\
\hline
\end{tabular}

Berdasarkan tabel tersebutdiketahui bahwa dari 24 orang siswa sebagai sampel penelitian yang hadir pada pre-test dalam pembelajaran membaca puisi sebelum menerapkan metode sugestopedia memperlihatkan nilai rata-rata yang rendah. Nilai rata-rata yang diperoleh siswa mencapai 68,58.

b. Hasil Pos-test

Pada pertemuan ini peneliti melakukan posttest dengan langkah-langkah sebagai berikut.

1) Peneliti menggunakan metode sugestopedia dengan alunan musik barat dan memberikan sugesti positif.

2) Siswa membacakan puisi dengan baik dan benar secara individu didepan kelas.

3) Peneliti melakukan penilaiaan.

Adapun kategori hasil pos-test kemampuan membaca puisi siswa kelas Empat SDN Ciwalet dapat dilihat pada tabel berikut. 
Tabel 4

Kategori Skor Kemampuan Membaca Puisi

Setelah Menerapkan Metode Sugestopedia

\begin{tabular}{|c|l|c|c|}
\hline Interval Nilai & \multicolumn{1}{|c|}{ Kategori } & $\begin{array}{c}\text { Frekuensi } \\
\text { (f) }\end{array}$ & $\begin{array}{c}\text { Persentase } \\
(\mathbf{\%})\end{array}$ \\
\hline $90-100$ & Sangat tinggi & 11 & 45,8 \\
\hline $80-89$ & Tinggi & 13 & 54,2 \\
\hline $70-79$ & Sedang & 0 & 0 \\
\hline $40-69$ & Rendah & 0 & 0 \\
\hline $0-39$ & Sangat rendah & 0 & 0 \\
\hline \multicolumn{2}{|l|}{ Jumlah } & 24 & 100 \\
\hline
\end{tabular}

Berdasarkan tabel tersebut dapat digambarkan bahwa perolehan nilai untuk klasifikasi di atas menunjukkan bahwa kelompok kategori sangat tinggi memiliki rentang nilai 90-100, kelompok kategori tinggi dengan rentang nilai 80-89, kelompok ketegori sedang dengan rentang nilai 70-79, kelompok kategori rendah dengan rentang nilai 40-69, dan kelompok kategori sangat rendah memiliki rentang nilai 39 ke bawah.

Hasil klasifikasi nilai pre-test kemampuan membaca puisi sesudah menerapkan metode sugestopedia menunjukkan bahwa tidak ada siswa yang memperoleh nilai dengan kategori sedang, rendah, dan sangat rendah. Pos-test yang diberikan kepada siswa menunjukkan bahwa siswa memperoleh nilai dengan kategori sangat tinggi yang dicapai sebanyak 11 orang (45,8\%), kategori tinggi sebanyak 13 orang (54,2\%). Hal tersebut menunjukkan bahwa kemampuan siswa dalam membaca puisi setelah menerapkan metode sugestopedia tergolong tinggi.

Tabel 5

Deskripsi Nilai Hasil Posttest Kemampuan Membaca Puisi Setelah Menerapkan Metode Sugestopedia

\begin{tabular}{|c|c|}
\hline Statistik & Nilai Statistik \\
\hline Sampel & 24 \\
\hline Nilai Terendah & 84 \\
\hline Nilai Tertinggi & 97 \\
\hline Nilai Tengah & 89,00 \\
\hline Rata-rata (mean) & 89,58 \\
\hline
\end{tabular}

Berdasarkan tabel tersebut deketahui bahwa dari 24 orang siswa sebagai sampel penelitian yang hadir pada pos-test dalam pembelajaran membaca puisi terhadap kemampuan membaca puisi sesudah menerapkan metode sugestopedia memperlihatkan nilai rata-rata yang tinggi. Nilai rata-rata yang diperoleh siswa mencapai 89,58. 
Untuk pengujian hipotesis, langkah yang dilakukan adalah menganalisis uji-t. Pengujian ini, digunakan dengan bantuankomputer yaitu program komputer sistem Statistik Product Service Solution (SPSS). Berdasarkan analisis uji-t (Paired Sample t-test) diketahui bahwa nilai signifikansi sebesar 0,000 lebih kecil dari signifikansi $0,05(0,000<0,05)$, maka hipotesis (Ha) dalam penelitian ini diterima. Dengan demikian, temuan ini terdapat pengaruh yang signifikan antara kemampuan membaca puisi sebelum menerapkan metode sugestopedia dan setelah menerapkan metode sugestopedia pada siswa kelas Empat SDN Ciwalet, dapat dilihat pada tabel berikut ini.

Tabel 6

Perbedaan Kemampuan Membaca Puisi Sebelum dan Sesudah Dilakukan Pembelajaran Menggunakan Metode Sugestopedia

\begin{tabular}{|c|c|c|c|c|c|}
\hline Variabel & Rerata & T hitung & Df & T tabel & Sig \\
\hline $\begin{array}{l}\text { Kemampuan membaca puisi } \\
\text { sebelum metode sugestopedia }\end{array}$ & 68,58 & 18.622 & 23 & 1.128 & 0,000 \\
\cline { 1 - 3 } $\begin{array}{l}\text { Kemampuan membaca puisi } \\
\text { setelah metode sugestopedia }\end{array}$ & 89,58 & & & & \\
\hline
\end{tabular}

\section{PENUTUP}

Berdasarkan data yang diperoleh dari hasil penelitian maka dapat disimpilkan bahwa adanya peningkatan kualitas membaca puisi pada siswa kelas IV SDN Ciwalet dengan diterapkannya metode sugestopedia terhadap pembelajaran tersebut.Peningkatan terlihat jelas pada perbandingan nilai rata-rata siswa sebelum dan sesudah diterapkannya metode sugestopedia. Sebelum diterapkannya metode sugestopedia rata-rata siswa sangat rendah dengan nilai 68,58 dan sesudah diterapkannya metode sugestopedia mengalami peningkatan dengan nilai rata-rata 89,58. Perbedaan yang sangat nyata ini dapat menjadi acuan bahwa metode sugestopedia layak digunakan dalam pembelajaran membaca puisi pada siswa kelas IV SDN Ciwalet.

Berdasarkan tindak lanjut dari penelitian ini, maka dapat ditemukan beberapa saran, antara lain sebagai berikut.

1. Bagi peneliti lebih memperluas wawasan dan memperdalam teknik pengelolaan dalam kelas, terutama dalam pembelajaran dengan menggunakan metode sugestopedia.

2. Bagi sekolah, diharapkan dalam proses pembelajaran menggunakan metode dan media pembelajaran lebih beragam agar siswa tidak merasa. 


\section{DAFTAR PUSTAKA}

Abdullah Sani, Ridwan. 2015. Inovasi Pembelajaran. Jakarta: Bumi Aksara.

Aminuddin. 2010. Pengantar Apresiasi Karya Sastra. Bandung; Sinar Baru Algendindo.

Ganie, Tajudin Noor. 2015. Buku Induk Bahasa Indonesia (Pantun, Puisi, Syair, Peribahasa, Gurindam dan Majas). Yogyakarta: Araska.

Hasanuddin, WS. 2002. Membaca dan Menilai Sajak. Bandung: Angkasa.

Listiani, Selly. 2014. Penerapan Metode Sugestopedia untuk Meningkatkan Kemampuan Menulis Puisi pada Mata Pelajaran Bahasa Indonesia (Penelitian Tindakan Kelas pada Siswa Kelas V SDN 6 Cikidang Kabupaten Bandung Barat Tahun Ajaran 2013/2014). UPI Institutional Repository. https://onesearch.id/Record/IOS2897.12037

Pangewa, Maharuddin. 2010. Perencanaan Pembelajaran. Makassar: Penerbit UNM.

Russel, Lou. 2011. The Accelerated Learning Fieldbook. Bandung: Nusamedi.

Situmorang, B. P. 1974. Puisi dan Metodologi Pengajarannya. Nusa Indah.

Situmorang, M., Sitorus, M., Hutabarat, W., dan Situmorang, Z., (2015), The Development of Innovative Chemistry Learning Material for Billingual Senior High School Students in Indonesia, Internationan Education Studies, 8(10): 55

Wiyanto, Asul. 2002. Terampil Bermain Drama. Jakarta: Grasindo.

Wiyanto, Asul. 2005. Kesusastraan Sekolah. Jakarta: Grasindo Anggota Ikapi. 